\title{
EDITORIAL: KOERS VOLUME 80, NO 3, 2015
}

\begin{abstract}
Author:
A Combrink ${ }^{1}$

\section{Affiliation:}

${ }^{1}$ Research associate, Department Languages and Literature, North West University.
\end{abstract}

\section{Correspondence to:}

A Combrink

Email: annette.combrink@nwu.ac.za

\section{Dates:}

8 Dec 2015

\section{How to cite this article:}

Combrink, A., 2015. "Editorial: KOERS Volume 80, No 3, 2015". KOERS - Bulletin for Christian Scholarship, 80(3). Available at: http://dx.doi.org/10.19108/ KOERS.80.3.2235

\section{Copyright:}

(C) 2015. The Author(s).

Published under the Creative

Commons Atribution License.
The number of articles available for publication in Koers (80) has led to the decision to publish a fourth issue for 2015. It has been decided that we should invite articles on specific burning and topical issues for 2016. One such issue is the whole matter of the higher education environment and the problems associated with it. The various campaigns and the initial hysteria have inculcated in university managements being very worried about what will happen in 2016 in terms of university admissions and especially the payment of fees, given the increasing financial pressures and the hugely inadequate help coming from the government in terms of projects such as NSFAS. Link to this the issue of "decolonization" which has been revived and about which more will be said in the fourth issue, and there is ample scope for reflection on what has been happening in 20 years of democracy.

A separate but related issue that would be fascinating to explore in philosophical and other terms is the attacking of symbols such as statues and other historical monuments, some of it driven by at least a modicum of historical awareness, such as the Rhodes statue (with the attendant irony of who the beneficiaries are of, for example, Rhodes Scholarships).

Die groot aantal artikels wat beskikbaar was vir publikasie in Koers (80) het die redaksie genoop om ' $\mathrm{n}$ vierde uitgawe vir 2015 te publiseer. Daar is ook besluit om vir doeleindes van 2016 se artikels skrywers te nooi om spesifieke brandende en aktuele sake aan te roer - een so ' $\mathrm{n}$ aangeleentheid is wat in die hoër onderwyslandskap aan die afspeel is. Die verskillende aanslae en die aanvanklike histerie het tot gevolg dat universiteitsbesture uiters bekommerd is oor wat in 2016 gaan gebeur, veral in die lig van die groeiende ekonomiese druk en die ontoereikendheid van finansiële ondersteuning vir studente, ook binne die konteks van die ontoereikende steun vanaf die NSFASskema. Koppel hieraan die hele kwessie van dekolonisering, en die verinheemsing van die kurrikulum, waaroor meer in die volgende uitgawe gesê sal word en dis duidelik daar baie ruimte is vir filosofiese en ander nadenke oor Suid-Afrika binne die konteks van 20 jaar van demokrasie.

Nog 'n saak wat van groot belang is, is natuurlik die hele kwessie van die aanvalle op beelde en ander historiese simbole en monumente. In sommige gevalle, soos met die Rhodes-verhaal, is daar weliswaar iets van ' $n$ historiese bewussyn (maar ook gepaardgaande ironie, siende dat Rhodes Studiebeurse nogal vrylik gebruik is deur sommige van die "beeldestormers").

Daar is ook ' $n$ behoefte uitgespreek vir meer resensies van belangrike publikasies oor veral die aktuele sake wat tans heelwat gesprekke aan die gang sit. E-pos gerus as u 'n publikasie het wat geresenseeer moet word, of stuur ‘n resensie van ‘n belangwekkende boek na annette.combrink@ nwu.ac.za

A need has been expressed for more reviews of important publications about especially the topical issues uppermost in people's mindsl. Do send an e-mail if you have a publication that should be reviewed, or send a review of such an important publication to annette.combrink@nwu.ac.za

In praktiese terme is besluit om wat die verwysingstyl betref terug te beweeg na die Harvard-styl. Meeste skrywers gebruik dit in elk geval en dan moet die bibliografie met groot moeite verander word na die huisstyl wat deur AOSIS voorgestaan is. 
Vanaf die eerste uitgawe van 2016 sal die Harvard-styl dus weer gebruik word. Voorbeelde sal verskaf word.

Annette Combrink

Hoof Redakteur, Koers

In practical terms it has been decided that the journal will revert to the use of the Harvard style of referencing. Most authors use it in any case, and then it is quite an onerous and laborious process to adjust a bibliography to the house style advocated by AOSIS.

From the first issue of 2016 the Harvard style will be used. Examples will be provided.

Annette Combrink

Editor-in-Chief, Koers 